\title{
AUDITORY MIDDLE LATENCY RESPONSE
}

\section{KIYOKO HORIUCHI}

Department of Otolaryngology, Faculty of Medicine, Shinshu University, Matsumoto

(Director: T.Suzuki, M.D.)

The properties of the auditory evoked response with peak latency of 6 to $50 \mathrm{msec}$, which was often referred as "middle latency response", were studied in order to examine its clinical significance.

The subjects used in this study were 8 adults, 5 young children aged from 2 years 2 months to 3 years 9 months and 4 infants aged from 12 months to 17 months. All the subjects were proved to have normal hearing. Active electrode was attached to the vertex while reference and ground electrodes were placed on one of the ear lobes and the root of the nose respectively. The responses were led to a medical computer through an amplifier and an analog filter set to pass bands of $1.8-2800 \mathrm{~Hz}$ in most cases, in order to minimize the effect of the filter on the recorded data. Two thousand signals were averaged in a test run and were recorded with an $X-Y$ recorder. Clicks were used for auditory stimulation.

The response pattern was relatively stable in adults and characterized by a polyphasic configulation with mean peak latencies of (Po) $6.4 \pm 0.31 \mathrm{msec}$, (Na) $16.7 \pm 1.87 \mathrm{msec},(\mathrm{Pa}) 28.4 \pm$ $3.82 \mathrm{msec}$, and $(\mathrm{Nb}) 40.3 \pm 2.84 \mathrm{msec}$ with the stimulus intensity of $60 \mathrm{dBHL}$. Po-peak seemed to correspond to the so-called BSR. The mean peak to peak amplitudes were $1.35 \pm 0.14 \mu \mathrm{V}$ (Po-Na), $1.38 \pm 0.25 \mu \mathrm{V}(\mathrm{Na}-\mathrm{Pa}), 1.34 \pm 0.12 \mu \mathrm{V}(\mathrm{Pa}-\mathrm{Nb})$, respectively (at $80 \mathrm{dBHL}$ ). In infants the response pattern was more variable and the peak latencies were shorter than those of adults except Po-peak. The mean peak to peak amplitudes in infants were smaller than those of adults and the values were different between the three parameters as in the following order; ( $\mathrm{Po}-\mathrm{Na}$ ) $>(\mathrm{Na}-\mathrm{Pa})>(\mathrm{Pa}-\mathrm{Nb})$. Threshold for Pa-peak was $10 \mathrm{dBHL}$ in adults, $25 \mathrm{dBHL}$ in young children and $40 \mathrm{dBHL}$ in infants.

The response pattern was altered with cut-off frequencies of the filter bands. The stability, threshold and identification of the response were improved with narrow bands of $22.4-180 \mathrm{~Hz}$ especially in infants. In clinical use of this response, the effective bands should be selected.

Although the frequency specificity of this response was not examined in the present study, it will be important problem in clinical application.

A79-1549-10522

\section{聴性誘発反応の middle latency response の検討*}

\author{
信州大学医学部耳鼻咽喉科学教室（主任：鈴木䉆郎教授) \\ 堀内㮮子
}

\section{鍺富。 \\ 他覚的悖力検査法の指標として使われている反応には}

*㮦器僟能検查法研究 第 104 報
いくつかあるが，それぞれに一長一短があり今だ満足す ヘさ方法が見出されていない. slow vertex response K よるいわゆる ERA は判定の信頼性に問題があり ${ }^{33) 34), ~}$

$12-17$ 
AP い, いわる brain stem response (以下 BSR) 该周波数态答性飞問題があり， $1,000 \mathrm{~Hz}$ 以下の低周波、 刺激音に対する情報が得られないと言われている6311

これらの問題点を解決できる可能性の期待できる反応 として, 最近 middle latency response (以下略して MLR とする) が注目されてきた。これは $6 \sim 50 \mathrm{msec}$ の所炕られる一連の謖性誘発反応で, 歴史的火は古く から報告されているが従来あまり普及しなかったすので ある. 今回我々はこの反応を他覚的聴力検查の指殹とし て臨床応用を目的飞検討した。

実 倹 方 法

図1 亿測定装置のブロックダイヤグラムを示す，測定 はシールドされた防音室で行われた．測定には脳波用デ 1スク電極を用い，探查電極頭頂部 $\mathrm{C}_{2}$, 基準電極を 一側耳垂，接地電極を鼻根上部に置いた。得られた反応 は前置增幅器 (日本光電 AVB-8) 時定数 0.3 秒で 500 倍増幅された後, 万能フィルタ（リオン $\mathrm{SA}-33 \mathrm{D}$ ) の 増幅部でさら飞 $30 \mathrm{~dB}$ 堌幅されるとともに，1.8-2,800 $\mathrm{Hz}$ の帯域フィルタを介し、コンピュータ（日本光電 $\mathrm{A}$ TAC-201）火導かれ加算平均された. 同時にこの反応 はデータレコーダ（TEAC R一200）飞記録され必要に より再生できるようKした，加算回数は 2,000 回，解析 時間は $50 \mathrm{msec}$ とし, 得られた反応は X-Yレコーダ （横河 3077）で書き出した。な和原波形をシンクロスコ ープ（岩崎 SS一5022）で観察した。

刺激音にはクリックを用いた。 万能刺激装置（日本光 電 MSE-40）加発生した $0.1 \mathrm{msec}$ の矩形波を減鼔 器 (東京光電 STA-114) 及び出力增幅器 (トリオ $M$ 一600）を通して測定室のスピーカK導きクリック音を 発生させた。刺激頻度は每秒 8 回 (間隔 $125 \mathrm{msec}$ ), 出 力は数人の正常成人の平均自敩域值を $0 \mathrm{dBHL}$ として記 載した、スピーカは被検者の一側耳亦より $97 \mathrm{~cm}$ の所 飞置き，一方コンデンサマイクロフォンをスピーカより $100 \mathrm{~cm}$ の所瞋きシンクロスコープ（岩崎 SS一5050） 飞導き刺激音が鼓膜飞達する時点をモニターした。

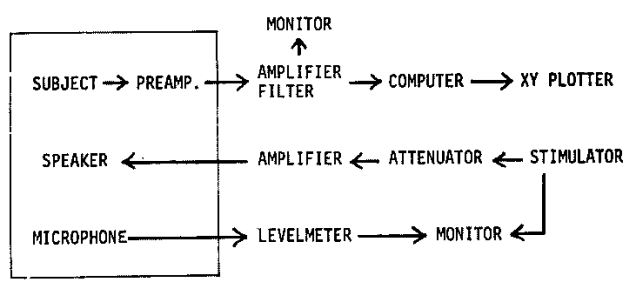

図 1 測定装圆のブロックダイヤグラム
被検者には聴力正常な党醒時成人 8 名, 睡眠時奻児 9 名（1歳～1歳 5 名月 4 名, 2 歳 2 名月～3歳 9 加月 5 名）を依頼した。

成 䄇

1. 度応波形

因 2 亿正常成人の典型波形を示した。 ここでは頭頂部 電極の陽性変動が上向きに記録されている.MLR の検 出には普通狭い帯域フィルタを使うが，ここでは反応を できるだけ原形に近い形でみようとし， $1.8-2,800 \mathrm{~Hz}$ という広い帯域フィルタを使用した．この波形をみると まず初めの $10 \mathrm{msec}$ 内に著明な陽性波がみられる。これ は BSR の第 5 波などといわれているピークであるが， 後述のよ万Kこれが Mendel $5^{20211}$ のいう Po と一致 するすのと思われる.この Po に次いで Mendel Бの いう $\mathrm{Na}, \mathrm{Pa}, \mathrm{Nb}$ components がみられる。この一連 の components の中で最む著明で安定なのは Po と Na であった. $\mathrm{Pa}$ は波形の variation 飞富み, 尖形ピーク のもの，山形のあの，なだらかな台状のあのなどがあっ た。 $\mathrm{Nb}$ はしばしば不明瞭となった。强い音刺激では $\mathrm{Na}$ ピークの前に小さな陰性ピークを認めることがあり（四 2, $80 \mathrm{dBHL}$ ), これは Mendel $5^{23) 24)}$ が $\mathrm{Na}_{1}, \mathrm{Na}_{2}$ と 分けたピークに相当する.

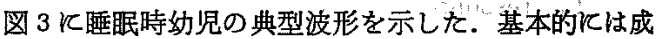

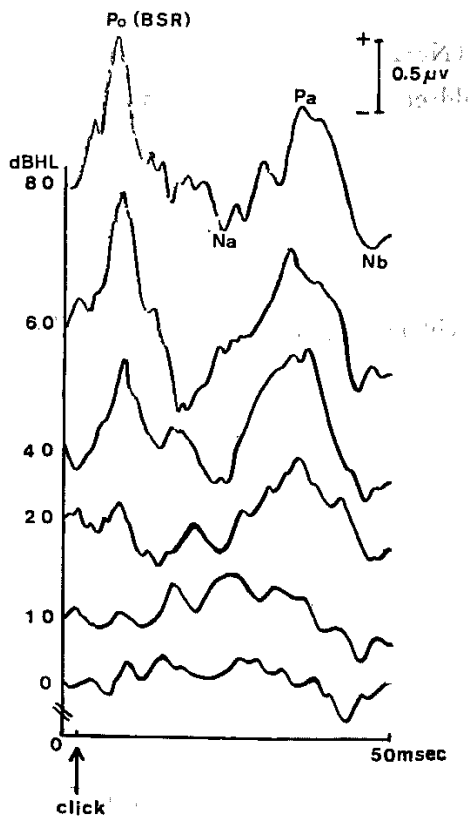

図 2 MLR の正常成人典型波形 25 歳 


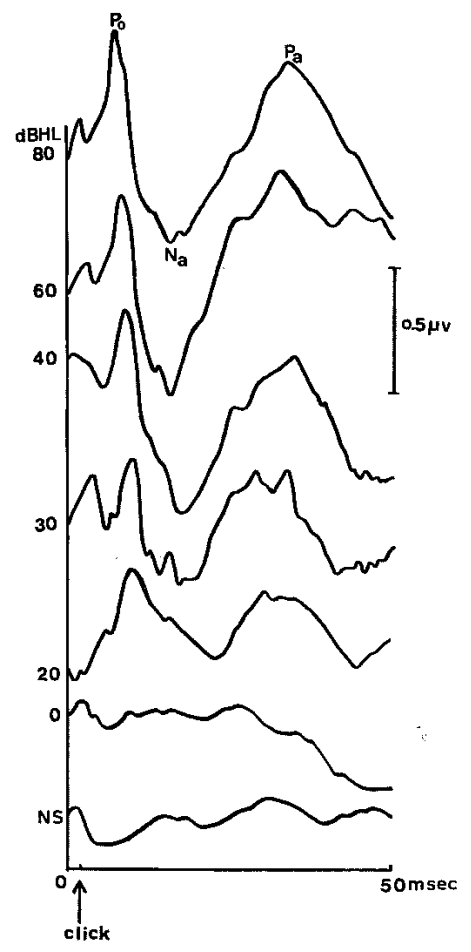

図 3 MLR の正常幼児典型波形 1 歳 9

人と同じであるが，成人より $\mathrm{Na}$ ピークが大きく潜時の 乹とが目立った．Pa 波形の variation は成人より 豊富であった。

\section{2. 反応潜時}

図 4 K各ピークの平均潜時を音刺激畾度別に示した。 潜時は音が鼓膜飞達した時点から各 component の最大 ピークまでの時間とした．各ピークとも音が小さくなる 《つれて潜時は延長し， $60 \mathrm{dBHL}$ で平均值および標

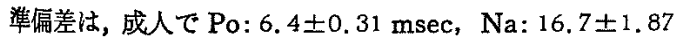
msec, $\mathrm{Pa}: 28.4 \pm 3.82 \mathrm{msec}, \mathrm{Nb}: 40.3 \pm 2.84 \mathrm{msec} \tau$ あり，幼児では Po: 6.8 $00.57 \mathrm{msec}, \mathrm{Na}: 13.4 \pm 1.93$ msec, Pa: $26.0 \pm 5.52 \mathrm{msec}, \mathrm{Nb}: 39.5 \pm 0 \mathrm{msec}$ であ った．成人と幼坚を比較して特徴的なことは，Poでは 幼見の方が潜時が和そいのに比ベて，他のピークでは幼 児の方加早くなっている. 特炕 $\mathrm{Na}$ では $3 \sim 7 \mathrm{msec}$ あ 早い.この差は成人と幼児の本質的なちがいか，それと ま睡眼などによる影響かはわからないが，興味ある問題 である。バラッキは Po, Na の早いピークほご小さく， $\mathrm{Pa}, \mathrm{Nb}$ のおそいピークほと大竞かった。

\section{3. 反応振幅}

图 5 Kピーク間振幅の 1 回当りの平均值を成人と幼児
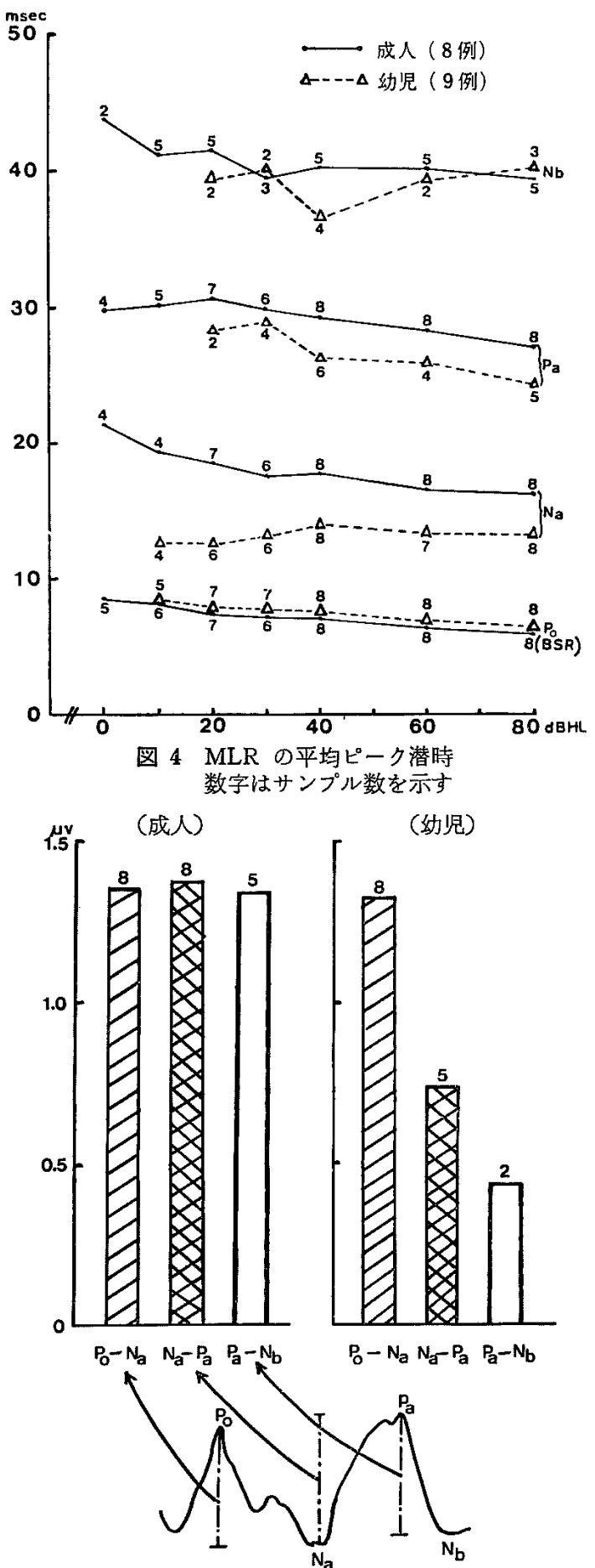

图 5 平均振幅(ピーク間比较) 音刺激強度は $80 \mathrm{dBHL}$ グラフ上の数字はサンプル数を示す 

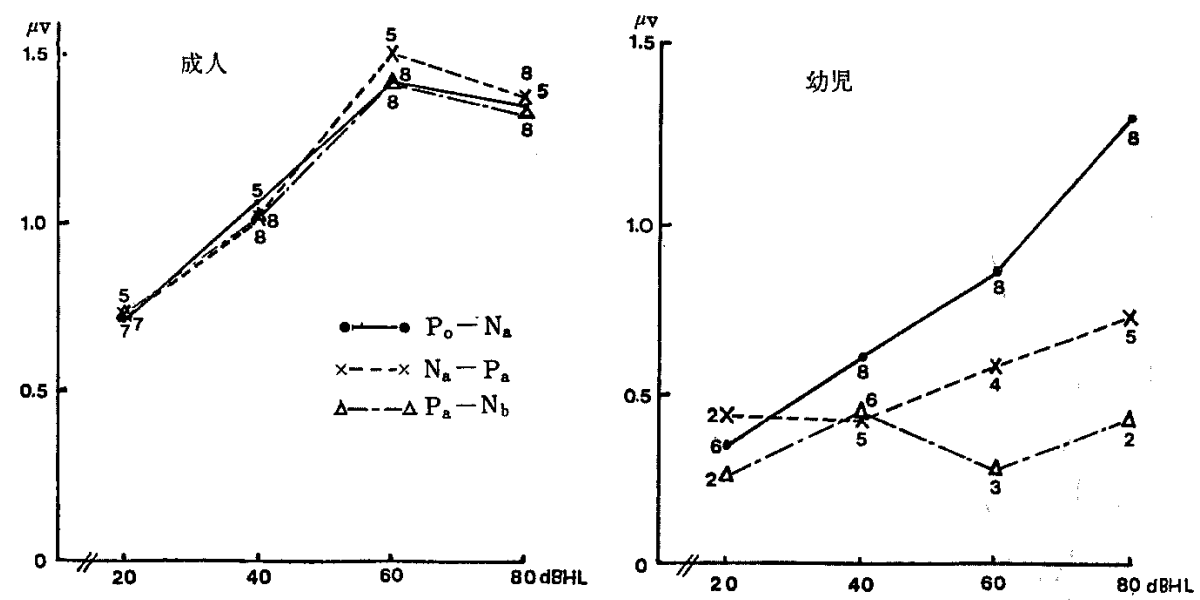

园 6 平均振幅 (音刺激強度比較) 数字はサンプル数を示す

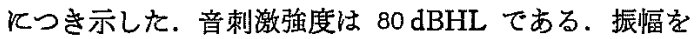
ピーク間で比較してみると成人では，Po- $\mathrm{Na}, \mathrm{Na}-\mathrm{Pa}$, $\mathrm{Pa}-\mathrm{Nb}$ の3者間にほとんど差がなく，それぞれ 1.35 $\pm 0.14 \mu \mathrm{V}, 1.38 \pm 0.25 \mu \mathrm{V}, 1.34 \pm 0.12 \mu \mathrm{V}$ でっっ が，幼児では $\mathrm{Po}-\mathrm{Na}$ が最皇大きく $1.33 \pm 0.20 \mu \mathrm{V}$, 次いで $\mathrm{Na}-\mathrm{Pa} の 0.74 \pm 0.22 \mu \mathrm{V}$, 最も小さいのは $\mathrm{Pa}$ 一Nb $0.44 \pm 0.05 \mu \mathrm{V}$ となり 3 者間飞差がるられ. 成人の $\mathrm{Po}-\mathrm{Na}$ 間振幅は幼児のそれとほぼ等しかった。 一般に振幅のバラッキはどのピーク間振幅です大きく， 幼児は成人のそれより大きかった。

図6亿振幅の音刺激強度比較を示した. 一般飞音が小 さくなると振幅も小さくなる傾向がみられた，成人では 3 個のピーク間振幅がほほ同じ程度に小さくなるが，幼 児では音が小さくなるにつれて 3 者間の振幅差はしだい に縮小している.すなわち幼児の $\mathrm{Po}-\mathrm{Na}$ 間振幅方，音 刺激強度により最す大きく変化する。一般汇音刺激強度 による振幅の変化は, 潜時の変化より著明であった.

4.フィルタの反応波形への影響。

反応記録系汇㨉入されたアナログフィルタ(リオン SA-330）Kより波形がどのようにかわるかを図７反示 した. 上段は通常我々が記録時に使用している広い帯域 フィルタを通した波形. 中段は Mendel $5^{29)}$ が使用し ていた 9-224 Hz という狭帯域フィルタを通した波形. 下段はさらに狭い $22.4-180 \mathrm{~Hz}$ 带域の波形て，これは 最近 McFarland $5^{18)}$ が MLR の検出飞最適だと称し て使用している帯域に近いものである，この図に示すよ うに㹨帯域フィルタを通すと波形は著明な变化を受け， 一般に Po は小さくなって見にくくなるが $\mathrm{Na}$ 以降の

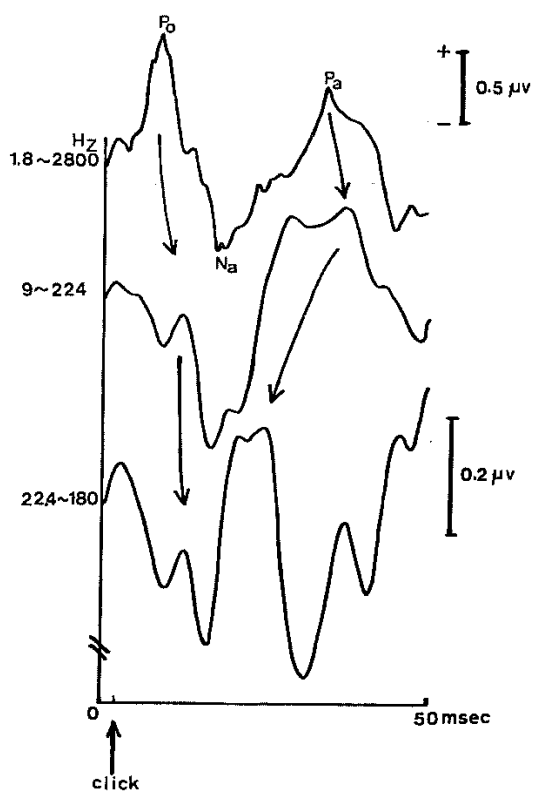

図 7 フィルタ波形 25歳。

components は大きく見易くなる．同時に各ピーク潜時 は延長すしくは短縮する。このような使用フィルタによ る反応の波形，振幅，潜時の変化仙研究者間のデータの 比較に無視できね問題であるとともに，反応検出のため の最適フィルタの選択が必要であることを示している.

5. 反応域值

表 1 K各ピークの平均反応域值を年齢別に示した. $1.8-2,800 \mathrm{~Hz}$ の広带域フィルタの場合にはPo 域值が 最す低い，纤児では， $\mathrm{Pa}$ 域值が $\mathrm{Na}$ 域值に比べて一段 
表 1 反応域值

\begin{tabular}{|c|c|c|c|c|}
\hline & フィルタ* & Po & $\mathrm{Na}$ & $\mathrm{Pa}$ \\
\hline & A & $\begin{array}{l}\mathrm{dBHL} \\
5.0\end{array}$ & 11.3 & 10.0 \\
\hline & B & 15.0 & 13.8 & 12.5 \\
\hline \multirow{2}{*}{ (2歳2月 2 紧 } & A & 12.0 & 14.0 & 25.0 \\
\hline & B & 21.0 & 11.0 & 12.0 \\
\hline \multirow{2}{*}{ 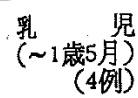 } & A & 22.5 & 30.0 & 45.0 \\
\hline & B & 25.0 & 25.0 & 25.0 \\
\hline
\end{tabular}

* 使用フィルタ通過帯域

A: $1.8 \sim 2,800 \mathrm{~Hz}$

B: $22.4 \sim 180 \mathrm{~Hz}$

と高くなっている傾向がみられた，年齢別てみると成人 の $\mathrm{Pa}$ 域值は $10 \mathrm{~dB}$ で最も低く，2歳 2 月以上幼児が $25 \mathrm{~dB} １$ 歳 5 月末満乳巟が $45 \mathrm{~dB}$ で, 最毛高加った。

これを 22.4-180 Hz の帯域フィルタをかけた場合と 比較してみると，Po 域值はどの年跉でも高くなる傾向 があり，Pa 域值は成人ではあまり差はないが，乳児， 幼児では一般に低くなる傾向が注目された。

6. 反応出現性

本反応の検出しやすさを出現率の立場からみるため， 图8 亿各ピークの反応出現率を示した. 成人の $\mathrm{Po}, \mathrm{Na}$, $\mathrm{Pa}$ の出現率はどの場合も高かった。 一方幼児ては 1.8 $\sim 2,800 \mathrm{~Hz}$ の広帯域フィルタ記録時では $\mathrm{Po}, \mathrm{Na}$ の出 琴率は高いが $\mathrm{Pa}, \mathrm{Nb}$ の出現率は低い。これを 22.4〜
$180 \mathrm{~Hz}$ の狭帯域フィルタ記録時でみると，Poの出現率 㹥くなるが $\mathrm{Pa}$ の出現率は著明飞高くなっている。

この結果より Po 以外の components の検出には適 当な帯域フィルタを使用した方が反応が判别しやすく， 検出率が良くなるょうと思われた。

7. myogenic response $\sigma$ 出現

本反応ではしばしば myogenic response との関連が 問題となる. 図9亿示した例は $60 \mathrm{dBHL}$ 以上の音刺激 の時飞 myogenic response と思われる, 振幅の大きな negative-positive 変動が現われたものである。これは加 算回数10回はどで，認められる大きさになる。またこの 大きな波形は音刺激が $40 \mathrm{dBHL}$ 程度に弱くなると出現 しなくなり，通常の振幅の小さい MLRのみとなる.こ の大きな myogenic response は通常の MLR より潜時 がやや早く negative peak が $13.7 \mathrm{msec}$, positive peak

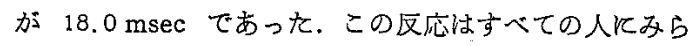
れるわけでなく，被検者間の出現性のバラッキが大きか った。また睡眠時幼児には 1 例もみられなかった。

\section{考 按}

MLR に関する報告は日本ではほとんどみられない が，この反応の歴史は古く1958年 Geisler ら゚がコンピ ュータによる加算平均の方法を導入してヒト頭皮上より 記録したのが初めである. 次いで1960年 Lowell ら 報告し，この反応の clinical audiometry への応用を示 昖している.その後, 後述するように反応の origin を めぐって多数の報告がなされた. 1964年 Bickford ら
$80 \mathrm{dBHL}$

(A)

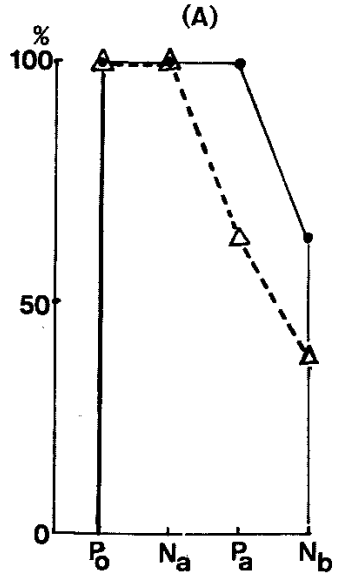

图 8 反応出現率
(B)

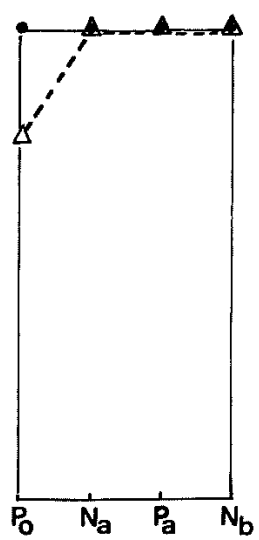

$20 \mathrm{dBHL}$

(A)

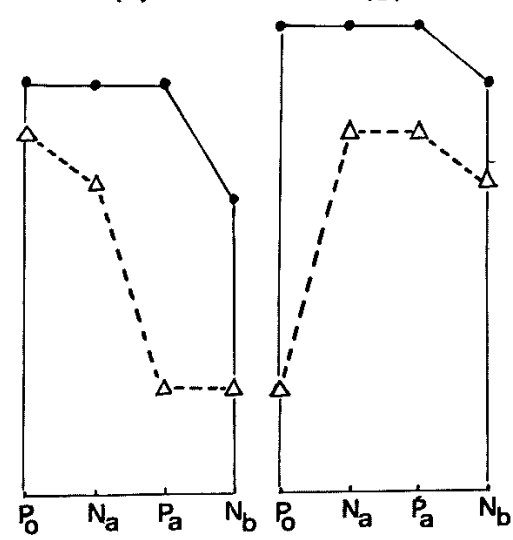

纤児

使用フィルタ通過帯域 A：1.8 2, 800 Hz, B: $22.4 \sim 180 \mathrm{~Hz}$ 


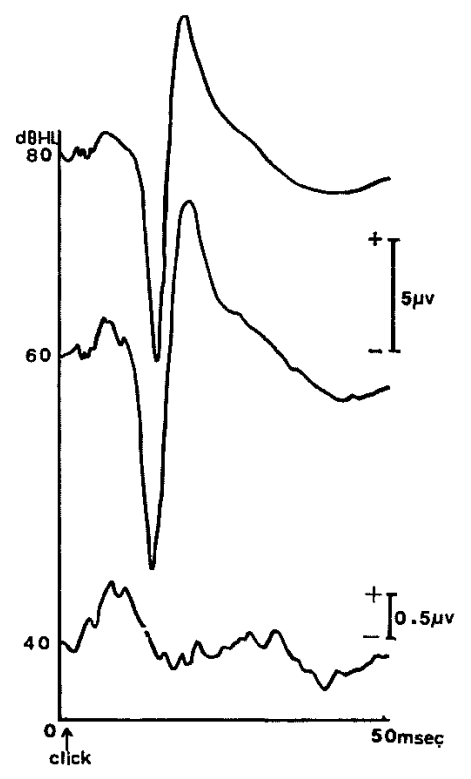

図 9 myogenic response の湿入例

が inion muscle による myogenic origin を提唱し， 一方 Lowell $5^{15}$ Goldstein \& $\operatorname{Rodman}^{10)}$ Бは neurogenic origin を支持した. また Borsanyi \& Blanchard $^{3)}$ † Mast $^{16) 17)}$ は両者の混合反応であるとし た. 1967年 Ruhm $5^{27}$ はヒトの開頭術前後で頭皮上と 皮質上よりこの反応を記録比較し，反応潜時がほとんど 同じであることより neurogenic response であること を証明した. その後 early components として Goldstein $5^{(0)}$, Mendel \& Kupperman ${ }^{12)}$ らにより詳細な 検討がなされ，最近は middle components あるいは middle latency response として報告が增えてきている. しかし slow vertex response, BSR, APなどK比べる と, その歷史の古さに比し臨床的普及が和くれているこ とは否定できない.

\section{1. 反流波形}

反応波形は報告によりとの細部は異なり，また命名も 異なるが，代表的なるのは Mendel \& Goldstein ${ }^{21)}$ (1969)の $50 \mathrm{msec}$ 内江みられる $\mathrm{Po}, \mathrm{Na}, \mathrm{Pa}, \mathrm{Nb} の$ 4 つの components を持つ波形である。この中で $\mathrm{Nb}$ は しはしば不明膫であるが， $\mathrm{Na} ， \mathrm{~Pa}$ はこの反応特有な ピークである。また音刺激が強い時には Naは2つに分 れるとして扣り ${ }^{23)}$ ，この現象は我々も観察している.Po ピークがこの components K加わったのは1969年の報

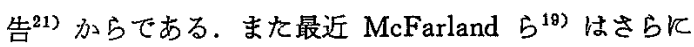

low cut filter を加えて Nb ピークのあとにもう1つ の陽性ピーク $\mathrm{Pb}$ を珰めている。

次に Po ピークに関しては，我々はこれが BSR の第 5 波などと言われている陽性ピークと一致するすのと考 えている(0). 図7K示したように Mendel らの使用し ているような狭い带域フィルタを同し反応に加けると， この陽性波が Mendel らの Po ピークと一致するのが 認められ，同じピークをフィルタのちがいルより別の立 場からみていたものと思われる。これ凬して Picton $5^{26)}$ は $\mathrm{Po}$ が, $\mathrm{Na}$ ピークの前の小さな陽性波であり BSR の第 5 波とはちがうあのとみて扣り，著者の前報 11てで同様に記載しているが，このピークは音が小さく なると消えてしまい Mendel らの観察した Po とは異 なると思う。

\section{2. 潜 時}

潜封もフィルタのかけ方により異なるため各報告をそ のまま比較することはできないが，我々のデータは Mendel \& Goldstein ${ }^{21)}$, Picton $5^{262}$ の成績とほほ似て いる. また $\mathrm{Na}$ と $\mathrm{Pa}$ の潜時は報告者間であまり差の ないのが特徴的で，この2つのピークがこの反応特有 で，安定なものであることがわかる．これに反して Po, $\mathrm{Nb}$ の潜時は報告者によりかなりの相选がある，音剌激 強度が小さくなると潜時が延長することはだれすが認め る所であるが，この割合は比較的小さく，振幅の変化ほ よ゙著明なものではない.

バラッキに関しては Mendel らは被検者間, 被検者 内とむに小さく，安定な反応であるとしているが，我々 の成績では，早いピーク $\mathrm{Po}, \mathrm{Na}$ のバラッキは小さい

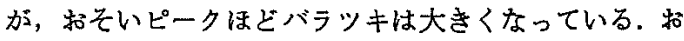
そいピークほど波形のシャープさがなくなり潜時として 測定する頂点の変動が大きく，これがバラッキの大きさ の原因をなしているすのと思われる。

3. 振 幅

ピーク間振幅すフィルタなどの測定条件によって大き く影響されるため，報告者間でかなりの相違が認められ るが, 30 50 dB 程度の刺激で $\mathrm{Na}-\mathrm{Pa}, \mathrm{Pa}-\mathrm{Nb}$ 問な どの振幅は大略 $0.5 \sim 1.5 \mu \mathrm{V}$ 前後である(12)18)21)27). 我 々の成績もほぼこの蓈用内にある，ピーク間で大きさを

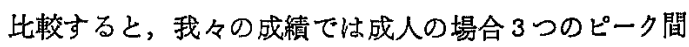
振幅にほとえど差はないが，幼児ではＰo-Na 間が特 に大きいのが目立ち，他のピーク間は成人より小さかっ た. 振幅のバラッキは被検者間で大きく，この程度は潜 時のバラッキより大きいように思われた。 
音刺激が小さくなると振幅が隇少することは多くの人 が謁かて打り，この減少の仕方は潜㭙の变化より著明 だと言われている ${ }^{15) 23)}$. Mendel $5^{222}$ は振幅が腄眠 stage て变化し，REM stage で最大となり睡眠が深い 活どさくなることを報告している。また刺激間隔とよ る振幅の変化行ついて, Geisler $5^{92}$ Lowell $5^{152}$ は 間隔が短くなるほど撗幅が小さくなることを認め，一方 McFarland $5^{18)}$ は 1 秒間 1 回と16回の刺激で振幅の変 化はなかったとしている。

\section{4. 纤児の反芯}

本反応の幼児関する報告は少ない，Engel ${ }^{\text {B) }}$ は新生 児について反応の桓常性のないことを述へているが， McRandle $5^{19)}$ はこれに反し，新生児の反応が波形， 潜時とも成人とほとんど差がなく, 反忘の安定性, 恒常 甠の良さ、信頼忙の高さを認めている。またこのことよ り本反応们関与する神経系は周座期の初期にすで成人 と同じ反応样式を示せるほどに完成しているらしいと述 ヘている.

我々の成績では，奻児の波形は基本的には成人と同じ であが，バラッキが大きく，安定性，恒常性は成人よ 呧加ヶ.この点は幼児の他覚的聴力検查飞忘用する 際問題となら万，潜時は Poのみ成人より革く，他のピ 一クはいずれも成人より早かった．特飞 Na の早いのが 特微的であった，振幅は成人より小さく，Po- $\mathrm{Na}$ 間振 幅方他のピーク間振幅に比でて大きいのが成人と異なる 点であった。 反応域值は成人より高く, 出現率も成人よ 低加った。これらの成人と幼児の反応のちがいがどこ からくるものかは加らないが，Na 以降の潜時が成人 より早くなることは他の auditory evoked response と 比ベて興味ある点であり今後の検討を要する。

5. 反応域值

ここで問題となるのは本反応の判定基準をどこに設け る加である. Geisler らす) は反応全体のパターンをみて， 成人の自党域值近〈まで追跡している. Goldstein $5^{10)}$

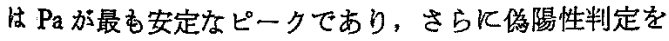
さけるため飞 $\mathrm{Na}-\mathrm{Pa}$ の combination 波形を判定の指 栖とし，成人で $-5 \mathrm{dBSL}$ まで検出している，他の報告 でる $\mathrm{Pa}$ を主体とした $\mathrm{Na}-\mathrm{Pa}-\mathrm{Nb}$ components 方指 摽とされて招り，Mendel ら ${ }^{25)}$ は乳䝨で 15 30dBHL の音剌澈で反忘が検出されたとしている。

我々の成續ではピークごとの反応域値をみると，早い と゚ーク活そ域值が低く，特に Poは他のピークに比べて 一皮之低い域值を持つ。しかし MLR の特性は $\mathrm{Pa} K$
あると思われるので， Na-Pa components を指標とす ると，この域值は成人で $10 \mathrm{dBHL}$ であり自觉域值沉か なり近い，幼児では 2 歳以上で $25 \mathrm{dBHL} １$ 歳 6 か月末 渵で $45 \mathrm{dBHL}$ と成人より高く，また他の報告よりあ高 くなっている。一方表1亿示したよろに狭い帯域フィル タを通すと，幼児域值はずっと低くなり，Mendel ら $5^{25)}$ の成績に近くなる，反刘飞

6. 反応出現性

出現性飞関して Goldstein $5^{103}$ は $\mathrm{Na}-\mathrm{Pa}$ を指標と すると $60 \mathrm{dBSL} て 585 \% ，-5 \mathrm{dBSL} て ゙ あ 55 \%$ とこ こ の反応の出現性の良さを述へ，Mendel ら ${ }^{21)}$ は成人睡眠 時で $50 \mathrm{dBSL}$ に対し 100\%の出現率を報告している. 乳児について Mendel $5^{25)}$ は 45, $60 \mathrm{dBHL} て ゙ 100 \%$ の反応が出現するとして伺り，また McRandle ら ${ }^{189}$ は 新生児10例のすべてで， $55 \mathrm{dBHL}$ 飞対し反态が得られ そとしている。このように多くの報告が本反応の出現性 の良さを述へ，特に slow vertex response に比べその 成績の良さを強調している ${ }^{19)}$.

我々の成績では $\mathrm{Na}-\mathrm{Pa}$ K関する出現率は，成人は高 いが奻児では $80 \mathrm{dBHL}$ でも $62 \% ， 20 \mathrm{dBHL}$ では $22 \%$ と他の報告に比でて低い，乙かしこれを $22.4-180 \mathrm{~Hz}$ の狭帯域フィル夕を通して比較してみると，成人は変化 ないが,幼児の出現率が著明に上昇する頃向がみられた。 このフィルタによる出現率のちがい忧，域值の場合と同 棦に興味ある問題と言える。

7. 睡眠の影響

本反忠はほとんど睡眠の影響を受けないといわれてい

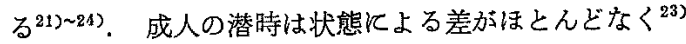
24)，振幅は deep sleep ほど小さくなるようである222. ま大明瞭な反応恬 REM stage で得られるが222, 臨床的 にはいずれでもをの検出汇影響しないとしている24)。同 样にこの反応は長時間記録しても habituationがなく， このようと睡眠の影響を受けない点, long term stability のある点は，この反応の origin が neurogenic である ことを示睃するむのであるとしている21).

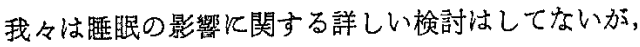
成人では覚醒でも睡眠でも反応の变化はほとんどない上 思われた。 また幼巟に括いて，少くとも slow vertex response の場合のような医眠深度による大きい影響は 認められなかった。

8. 反㤁の安定性, 恒常性, 信賴性

本反応の安定性の良さ飞関する報告は多〈2)10222223)27), 恒常性も高いといわれている. 特に Pa は安定したピー 
クとされている10). またこれらの安定性は被検者の状

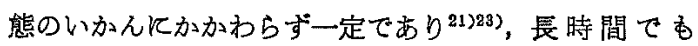
habituation がなく, long term stability があるとして いる21222．またこれらの現象は, 新生児でも認められて いる19). 我々の成績では成人の場合は波形，潜時とむに 比較的安定しているが，睡眠時奻児では波形のバラッキ が大きかった．乙かし幼児であ Po，Na ピークは安定し ていた。 また時化大きな myogenic response が混入し てくることがあり，波形のバラッキを大きくした，反応 の恒常性については, 今後さらK詳しい検討を必要とし よろ.

判定の信頼性次いて McRandle $5^{19)}$ は, 睡眠時奻 児で検討し，本反応は false positive，negative が少く， slow vertex response K比へてはるか信頼性が高いこ とを述へててる。これは，この反応が幼児の睡眠時脳波 の影響を受けることが少ないためであるうと思われる。

\section{9. 反応の origin}

この反応の origin Kついては古くから缕論されて和 り，現在までのところろつの意見がある１つは Geisler $ら^{8)}$ 以来多くの人が提唱している neurogenic origin. この根拠は, 反応の安定性, 恒常性, 頭皮上の広い領域 から同し反応が得られることなどで，彼はこの反応が anditory cortex 深部由来と推測している。すう 1 つは

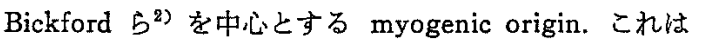
強い音刺激を与えて inion muscle を祭張させると本反 応の振幅が大きくなり，他緩させると振幅が小さくなる 事実を根挆としたものである.3つ目は Mast ${ }^{10317)}$ の提 唱する neurogenic と myogenic の混合反応とする説 である。

neurogenic 説を支持するあのとしては Lowell $5^{15)}$, Goldstein \& Rodman $5^{10)}$ で, さらK Ruhm $5^{27)}$ 大脳皮質上よりの記録により cochleoneurogenic origin

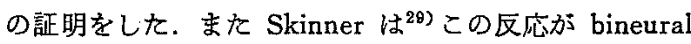
summation の効果があることょり, primary neurogenic basis 由来であるとし，McRandle ${ }^{19)}$ は潜時の一定し ていることや睡眠 stage の影響を受けないことより， primary auditory system $の$ lemniscal system 由来で あるとしている. 一方 myogenic response 説支持とし ては Townsen \& $\mathrm{Cody}^{32)}, \operatorname{Cody} 5^{435)}$ の報告がある.

最近 Picton $5^{26)}$ 活詳細な検討の結果, この反応が招 そらく auditory thalamus と cortex の活動を表わする のであるが，これ頭皮上の筋原性の反応が混入して反

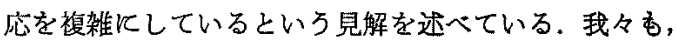

この反応が単独の origin 由来ではなく, Borsanyi ら， Mast, Picton らの言うように両者あるいはまだ何か他 の generator からの混合反応ではないかと思う。因9 飞示すような，大きな音て時飞出現する myogenic response と本反応とは，はっきりと区別できるが, 頝部, 側頭部などの筋を緊張させると，MLR のピーク振幅が 大きくなるという事実は，MLR 自身化何らかの myo genic の要素が関与していることを示唆しているものと 思われる.

10. フィルタの使用関して

前述のごとく従来の報告は反応決い帯域つィルタを かけて記録されている，反态にフィルタをかけると，特 定周波数の power が減少し，これを適当汇設定するこ とにより S/N 比を改善し波形をきれいに見やすくし， 反応の検出を容易にする効果があるが，一方，特化減衰 特性のよいフィル夕を使用した場合には，著明な位相の 遅速をひき扚こし，反応波形，潜時，振幅などの変化をき たす しかし従来はあまりこのことに関心が払われず， 異なった通過帯域のフィルタを使用した成續が直接比較 されるということも桸でなかった．最近 Lane ら ${ }^{14)}$ は 本反応のいくつ加の positive \& negative wave はそれ ぞれ異なった spectrum energy を持っており，それら は $20-200 \mathrm{~Hz}$ の間炕存在するという報告をしている. これをふまえて McFarland ら ${ }^{18)}$ は $25-175 \mathrm{~Hz}$ のフ ィルタ setting 推奖して扣り，これ低低波数の高振 幅成分を除くことによって視覚的に反応をとらえること が容易であるといわれている，我々の成績でも，フイル 夕の使用に上る波形の変化, 反応域値や反応出現率への 大さい影響が認められた. 従ってどのような帯域フィル 夕を用いるのが最適であるかは，今後の検討が待たれる 大きな問題である.

10. 臨床応用について

この反応の臨床応用, 主として他覚的域值測定の可能

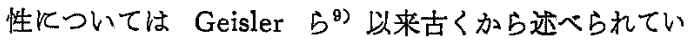
る. 我々むこの反応がその性質上, slow vertex response より信頼性の高い域值検查法の指標として，幼児伈応 する可能性は充分あると思う．しかし我々の成樍で䧼 眠時幼児で安定した反応を恒常的に検出し得ると至って 括らず，この点で記録方法上の改善が必要で㟧る。また 病巣の鑑別診断として利用するには origin 飞関する検 索がさらに望まれる。

臨床応用で最も期待されるのはこの反応の周波数応答 性である. AP，BSR のよう飞潜時の早い反忘は主とし 
$\tau 2,000 \mathrm{~Hz}$ 以上の高周波数音化対して反応し，1,000 $\mathrm{Hz}$ 以下の低周波数音隹対する情報は得難いといわれて いる.しかし難㯖児では $1,000 \mathrm{~Hz}$ 以下の低周波数音で の残德度がしばしば問題となり、これに対する情報の得 られる検查法が望まれていた。この反応の tone pips 対する出現性は clicks と玨と九どかわらず，域值は 250 $\mathrm{Hz}$ で $20 \mathrm{dBSL}, 1,000 \mathrm{~Hz}, 4,000 \mathrm{~Hz}$, clicks で $10 \mathrm{~dB}$ SL と報告されている ${ }^{12)}$. Pure tone K対しては 1,000 $\mathrm{Hz} て ゙$ rise \& decay time をがた場合の反応出現性

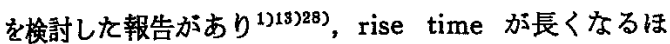
と振愊が小さくなり，波形の安定性がなくなることを観 察している. 1,000 Hz 以下の pure tone 飞対する報告 はまだない，この反応が $1,000 \mathrm{~Hz}$ 以下の低周波数音に 反応するかどうかについては今後さらに検討しなりれば ならぬがその可能性は充分にある．その際には反応の検 出方法加問題となろう。

\section{鞊語}

ヒト頭頂部より導出した潜時 $6 \sim 50 \mathrm{msec}$ の聴性誘発 反応である middle latency response そついて，その特 性と，他覚的域值椡定への応用の可能性を㭘討した。 こ の反店は成人で活安定して打り反応域值す低いが，睡眠 時奻览で，かなりバラッキが大きかった．しかし反応 波形はフィルタとより大きくかわり，22.4-180 Hz の

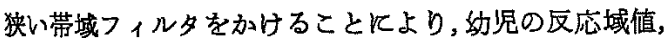

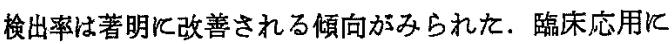
際しては，今後，特飞本反応の $1,000 \mathrm{~Hz}$ 以下の刺激音 飞対する店答性の検討と，反応検出のための最適フィル 夕の選択方必要と思われた。

\section{参考 文 献}

1) Beiter, R.C. and Hogan, D.D.: Effects of variations in stimulus rise-decay time upon the early components of the auditory evoked response. Electroenceph. clin. Neurophysiol., 34; 203-206, 1973.

2) Bickford, R.G., Jacobson, J.L. \& Cody, T.R.: Nature of average evoked potentials to sound and other stimuli in man. Ann. N.Y. Acad. Sci., 112; 204-223, 1964 .

3) Borsanyi, S.J. \& Blanchard, C.L.: Auditory evoked brain response in man. Arch. Otolaryngol., 80; 149-154, 1964.

4) Cody, D.T.R., Jacobson, J.L., Walker, J.C. E
Bickford, R.G.: Averaged evoked myogenic and cortical potentials to sound in man. Ann. Otol. (St. Louis), 73; 763-777, 1964.

5) Cody, D.T.R. \& Bickford, R.G.: Averaged evoked myogenic responses in normal man. Laryngoscope, 79; 400-416, 1969.

6) Davis, H. \& Hirsh, S.K.: The audiometric utility of brain stem responses to low-frequency sounds. Audiology, 15; 181-195, 1976.

7) Dawson, W.W. and Doddington, H.W.: Phase distortion of biological signals: Extraction of signal from noise without phase error. Electroenceph. clin. Neurophysiol., 37; 663-669, 1974.

8) Engel, R.i Early waves of the electroencephalic auditory response in neonates. Neuropaediatric., 3；147-154，1971. (文献19上り引用)

9) Geisler, C.D., Frishkopf, L.S. and Rosenblith, W.A.: Extracranial responses to acoustic clicks in man. Science, 128; 1210, 1958.

10) Goldstein, R. E Rodman, L.B.: Early components of averaged evoked responses to rapidly repeated auditory stimuli. J. Speech \& Hearing Res., 10; 697-705, 1967.

11）堀内潔子：㯖性䍁幹反応とその臨休応用飞関する研 究. 日耳甶，78；23-35，1975.

12) Kupperman, G.L. and Mendel, M.I.: Threshold of the early components of the averaged electro encephalic response determined with tone pips and clicks during drug-induced sleep. Audiology, 13; 379-390, 1974.

13) Lane, R.H., Kupperman, G.L. छ Goldstein, R.: Early components of the averaged electroencephalic response in relation to rise-decay time and duration of pure tones. J. Speech \& Hearing Res., 14; 408-415, 1971.

14) Lane, R.H. Mendel, M.I., Kupperman, G.L., Vivion, M.C., Buchanan, L.H. E Goldstein, R.: Phase distortion of averaged electronencephalic response. Arch. Otolaryngol., 99; 428-432, 1974. 15) Lowell, E.L., Troffer, C.I., Warburton, E.A. E Rushford, G.M.: Temporal Evannation; a new approach in diagnostic audiology. J. Speech \& Hearing Disord., $25 ; ;_{3}^{* \pi} 340-345,1960$. 
16) Mast, T.: Muscular vs. cerebral sources for the short-latency human evoked responses to clicks. Physiologist, 6; 229, 1963.

17) Mast, T.: Short latency human evoked responses to clicks. J. Appl. Physiol., 20; 225-730, 1965.

18) McFarland, W.H., Vivion, M.C., Wolf, K.E. $B$ Goldstein, R.: Reexamination of effects of stimulus rate and number on the middle components of the averaged electroencephalic response. Audiology, 14; 456-465, 1975.

19) McRandle, C.C., Smith M.A. \& Goldstein, R.: Early averaged electroencephalic responses to clicks in neonates. Ann. Otol., 83; 695-702, 1974.

20) Mendel, M.I. \& Goldstein, R.: The effects of test conditions on the early components of the averaged electroencephalic response. J. Speech \& Hearing Res., 12; 344-350, 1969.

21) Mendel, M.I. \& Goldstein, R.: Stability of the early components of the averaged electroencephalic response. J. Speech \& Hearing Res., 12; 351$361,1969$.

22) Mendel, M.I. and Goldstein, R.: Effect of sleep on the early components of the averaged electroencephalic response. Arch. Klin. Exp. Ohr.-, Nas.-u. Kehlk. Heilk., 198; 110-115, 1971.

23) Mendel, M.I.: Influence of stimulus level and sleep stage on the early components of the averaged electroencephalic response to clicks during all-night sleep. J. Speech \& Hearing Res., $17 ; 5-17,1974$.

24) Mendel, M.I. \& Kupperman, G.L.: Early components of the averaged electroenphalic response to constant level clicks during rapid eye movenent sleep. Audiology, 13; 23-32, 1974.

25) Mendel, M.I., Adkinson, C.D. and Harker, L.A.: Middle components of the Auditory evoked potentials in infants. ERA Newsletter, No. 39; $23,1975$.

26) Picton, T.W., Willyard, S.A., Krausz, H.I. and Galambos, R.: Human auditory evoked potentials. I: Evaluation of components. Electroencep. clin. Neurophysiol., 36; 179-190, 1974.

27) Ruhm, H., Walker, E. and Flanigin, H.: Acoustically evoked potentials in man: Mediation of early components. Laryngoscope, 77 ; 806-822, 1967.

28) Skinner, P. and Autinoro, F.: The effects of signal rise time and duration on the early components of the auditory evoked cortical response. J. Speech \& Hearing Res., 14; 552-558, 1971.

29) Skinner, P. Eo Shimota, J.: Binaural summation and the early components of the auditory electroencephalic response. J. Auditory Res., 12; $32-35,1973$.

30）鉿木篤郎，场内橴子，小泉 智：聴性媨幹反応の波 形飞阙古考察. Audiology Japan, 19; 1976.

31) Teas, D.C., Eldredge, D.H. \& Davis, H.: Cochlear responses to acoustic transients: an interpretation of whole-nerve action potentials. $\mathrm{J}$. Acoust. Soc. Amer, 34; 1438-1459, 1962.

32) Townsend, G.L. and Cody, D.T.R.: The averaged inion response evoked by acoustic stimulation: Its relation to the saccule. Ann. Otol. Rhin. Laryng., 80; 121-131, 1971.

33）山本香列：堎笔反応湘定における判定に関する研 笁。日耳舞，77；641-649，1974。

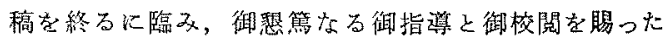
恩師鈴木䈍郎教授に染甚なる謝意を表します。また終始

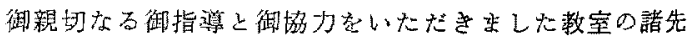
生方に梁謝いたします。

（原稿受付 昭和51。6，1日） 